\title{
Recycled ionic liquid 1-ethyl-3-methylimidazolium acetate pretreatment for enhancing enzymatic saccharification of softwood without cellulose regeneration
}

\author{
Umi Hamidah ${ }^{1,2} \cdot$ Takuya Arakawa $^{1} \cdot$ Yin Ying H'ng ${ }^{1} \cdot$ Akiko Nakagawa-izumi $^{1} \cdot$ Masanori Kishino $^{3}$
}

Received: 18 August 2017 / Accepted: 10 November 2017 / Published online: 12 December 2017

(C) The Japan Wood Research Society 2017

\begin{abstract}
In this work, pretreatment of wood meals using a recycled ionic liquid (IL), 1-ethyl-3-methylimidazolium acetate ([Emim] Ac), enhanced glucose liberation by enzymatic saccharification, without dissolution of cellulose and lignin. In contrast, previous studies on IL pretreatment have mostly focused on lignocellulosic dissolution to regenerate cellulose and removing lignin. Softwood (Cryptomeria japonica) was pretreated with [Emim]Ac at $60-100{ }^{\circ} \mathrm{C}$ for $2-8 \mathrm{~h}$ without collecting regenerated cellulose. The pretreatment did not have a strong effect on wood component dissolution (weight of residues: 91.7-98.8\%). The residues contained relatively high amounts of lignin (26.6-32.6\%) with low adsorption of [Emim]Ac $(0.9-2.7 \%)$. Meanwhile, the crystallinity index $\left(C_{\mathrm{r}} I\right)$ of cellulose in the wood was significantly reduced by pretreatment, from $50.9 \%$ to $28.4-37.1 \%$. In spite of the high lignin contents in the residues, their glucose liberation values by enzymatic saccharification using a cellulase mixture were 3-16 times greater than that of untreated wood. A good correlation was found between the saccharification effectiveness of pretreated samples and the $C_{\mathrm{r}} I$. Although lignin dissolved in [Emim]Ac continued to accumulate after repeated use of [Emim]Ac, the pretreatment was found to be effective for three consecutive cycles without the need to remove the dissolved materials.
\end{abstract}

Keywords 1-Ethyl-3-methylimidazolium acetate $\cdot$ Softwood $\cdot$ Cellulose regeneration $\cdot$ Enzymatic saccharification · Cellulose crystallinity

\section{Introduction}

Wood is a prominent sustainable source of biomass, because of its huge stocks and the fact that it does not directly compete with food production. Materials derived from wood can be used as feedstock to produce valuable chemicals. In particular, cellulose in the wood can be used to generate biofuels and other bio-based products. The softwood forest in

Akiko Nakagawa-izumi

nakagawa-izumi.a.gm@u.tsukuba.ac.jp

1 Graduate School of Life and Environmental Sciences, University of Tsukuba, 1-1-1 Tennodai, Tsukuba, Ibaraki 305-8572, Japan

2 Research Unit for Clean Technology, Indonesian Institute of Sciences (LIPI), Jalan Sangkuriang, Komplek LIPI Gedung 50, Bandung 40135, Indonesia

3 Forest Products Research Institute, Hokkaido Research Organization, 1-10 Nishikabura, Asahikawa, Hokkaido 071-0198, Japan
Japan has not been well-managed. The amount of softwood plantation in Japan was 3.0 billion $\mathrm{m}^{3}$ in 2012 . However, the self-sufficiency rate of industrial wood is only $31.2 \%$ in 2014 , and the utilization of wood resources is insufficient [1]. Therefore, it is necessary to develop novel methods to separate and collect wood-derived materials. In this study, we focus on a softwood that is endemic to Japan (Cryptomeria japonica). Unfortunately, biotransformation of lignocellulosic biomass is not easy by either microbial or enzymatic routes, thereby limiting its economic conversion into value-added products. The cellulose in wood has a crystalline structure and is covered with lignin and hemicellulose. Therefore, pretreatment is very crucial for the efficient transformation of lignocellulosic biomass.

Several researchers reported the dissolution of lignocellulosic materials in ionic liquids (ILs) followed by cellulose hydrolysis with acid or enzymes [2-6]. The ILs are liquids at a relatively low temperature $\left(<100^{\circ} \mathrm{C}\right)$ consisting of a cation and an anion. They are chemically and thermally stable, non-flammable, non-volatile, and have low vapor pressures. 
They also have greatly variable chemical and mechanical properties. Hence, ILs have attracted attention as environment-friendly media for chemical reactions and as solvents in extraction [3, 4, 7, 8]. Swatloski et al. [9] first reported the dissolution of cellulose in ILs, and this was followed by many related studies [10]. Wood, especially softwood, can dissolve in various ILs such as a mixture of 1- $n$-butyl3 -methylimidazolium chloride $([\mathrm{Bmim}] \mathrm{Cl})$ and dimethyl sulfoxide (DMSO) [4, 5], and then pure cellulose could be separated. Miyafuji et al. [7, 11, 12] reported that wood components such as cellulose, hemicellulose, and lignin are depolymerized during liquefaction by ILs treatment. The authors concluded that the liquefaction of softwood and hardwood with 1-ethyl-3-methylimidazolium chloride $([\mathrm{Emim}] \mathrm{Cl})$ is not homogeneous from both chemical and morphological viewpoints. The morphological changes were also analyzed using optical and scanning electron microscopy methods $[7,11,12]$.

The ability of ILs to dissolve wood depends on the type of wood, dissolution time, temperature, and IL composition [10]. The dissolution rates of carbohydrates such as cellulose and hemicellulose in wood components are much faster than that of lignin. Consequently, the lignin is concentrated in the residue after the dissolution of wood material in an IL, such as [Bmim] $\mathrm{Cl}$ [13]. For lignocellulosic materials, 1-Ethyl3-methylimidazolium acetate ([Emim]Ac, Fig. 1) is among the most promising candidates for industrial applications, due to its non-corrosiveness, non-toxicity, and biodegradability [10]. Mood et al. used five different ILs to treat barley straw, and found that [Emim]Ac was the most efficient in cellulose conversion [14]. Both softwood (southern yellow pine) and hardwood (red oak) can be completely dissolved in [Emim]Ac after mild grinding, with red oak dissolving more completely and faster than southern yellow pine [6].

The majority of lignocellulosic pretreatment methods have focused on reducing the lignin content and cellulose crystallinity, without destroying the fermentable sugars of the lignocellulose $[2,15]$. It is believed that increasing the accessibility of cellulose is more important than removing lignin for high sugar yields $[16,17]$. Enzymatic saccharification and acid hydrolysis are used for producing glucose from cellulose. Enzymatic saccharification

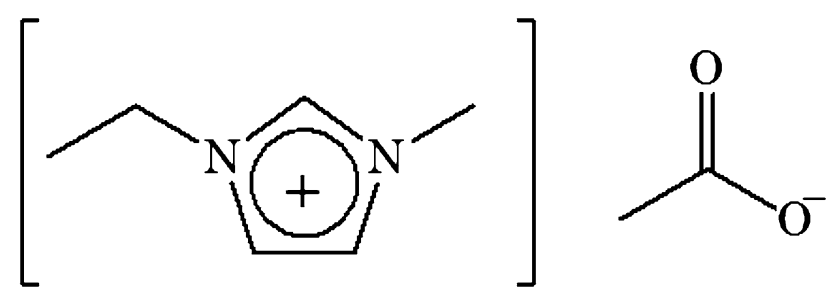

Fig. 1 The chemical structure of 1-Ethyl-3-methylimidazolium acetate $([\mathrm{Emim}] \mathrm{Ac})$ has some advantages: the hydrolysis can be carried out at lower temperatures, and the glucose liberation is higher than that of acid hydrolysis $[2,15]$. Factors affecting the enzymatic hydrolysis of cellulose after ILs pretreatment have been studied [2], and cellulose crystallinity is considered a key predictor of the enzymatic saccharification performance [18].

The ILs can be recovered after the regeneration of cellulose with water or water/acetone mixture. The solvent added to the ILs should be evaporated prior to its reuse in the next extraction cycle. Recycling and reusing ILs could help make the process more practical and environment-friendly for industrial applications. [Emim]Ac, which has been demonstrated as an effective IL with excellent recyclability [15, 19], was examined as the solvent in this study.

Herein, [Emim]Ac is tested in an efficient pretreatment method to amorphize cellulose in wood materials for enhancing enzymatic saccharification without collecting regenerated cellulose. This could be a new and simpler process for softwood. The effects of treatment time and temperature are estimated. Then, using the proposed method, the recyclability of [Emim]Ac was studied without removing the dissolved materials.

\section{Materials and methods}

\section{Materials}

Wood meals (40-80 mesh) from C. japonica with a moisture content of around $10 \%$ were used for the IL pretreatment. [Emim]Ac with $>95 \%$ purity was purchased from IoLitec Ionic Liquids Technologies Inc. Microcrystalline cellulose powder was purchased from Aldrich Chemical Company, Inc., USA. A cellulase mixture (GC220) was provided by Genencore Kyowa Co. Ltd., Japan. Filter paper (Advantec No. 1) was used as a control substrate for comparison.

\section{Separation procedure of [Emim]Ac pretreatment (collecting regenerated cellulose)}

The wood meals were previously extracted with ethanol-benzene (1:2, v:v). Afterwards, $1.25 \mathrm{~g}$ of oven-dried wood meals were treated with $25 \mathrm{~g}$ of [Emim]Ac at $80^{\circ} \mathrm{C}$ for $72 \mathrm{~h}$. The mixture was washed with DMSO and acetone, then separated into the residue and filtrate using a glass filter (1GP16). Excess water was then added to the filtrate to obtain regenerated cellulose in the form of precipitation. The precipitate was separated by centrifugation and washed with water. Meanwhile, the residue was separately washed with water (see the process in Fig. 2a). 


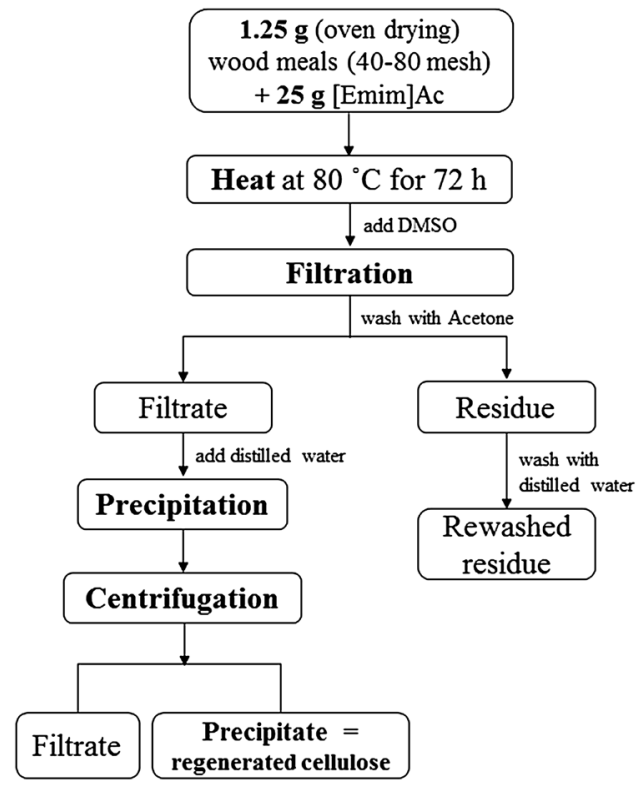

(a)

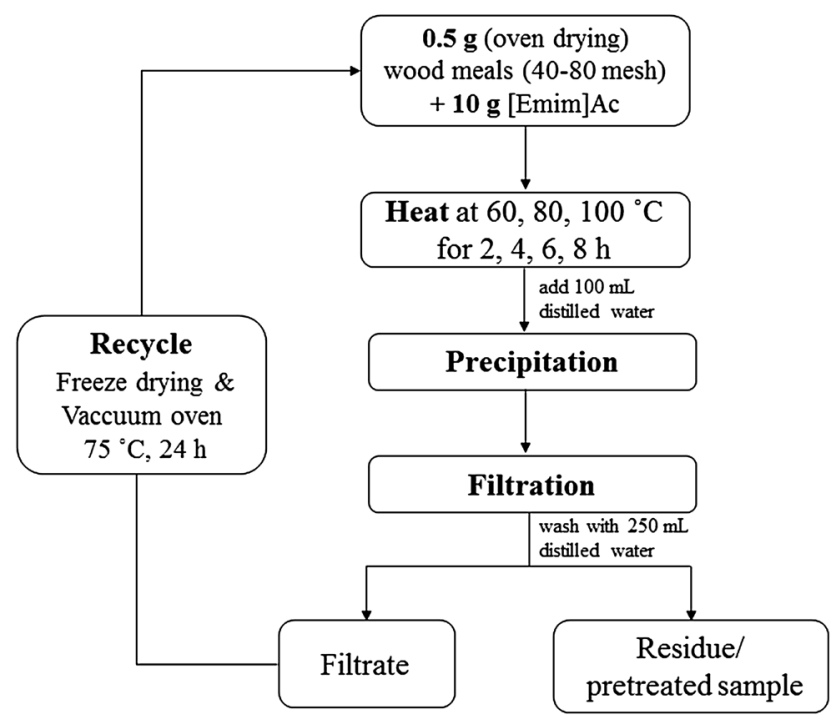

(b)

Fig. 2 Scheme of [Emim]Ac pretreatment (a) separation procedure: collecting regenerated cellulose, (b) a proposed non-separation procedure: without collecting regenerated cellulose

\section{Non-separation procedure of [Emim]Ac pretreatment}

Wood meals $(0.5 \mathrm{~g})$ with $10 \mathrm{~g}$ [Emim]Ac were placed in a round flask and heated in an oil bath at 60,80 , and $100{ }^{\circ} \mathrm{C}$ for $2,4,6$, and $8 \mathrm{~h}$, while being mixed with a magnetic stirrer. After the ILs pretreatment, $100 \mathrm{~mL}$ of distilled water was added to the flask, and then the mixture was filtered using a $1 \mathrm{GP} 16$ glass filter. Residue on the filter was washed with $250 \mathrm{~mL}$ of distilled water (see the process in Fig. 2b). After drying overnight in an oven at $105^{\circ} \mathrm{C}$ to remove excess water, the residue was subjected to chemical characterization and enzymatic saccharification.

\section{Recovery and reuse of [Emim]Ac}

The [Emim]Ac gathered from softwood pretreatment was reused, without removing the dissolved materials. The subsequent residue and filtrate were obtained using the same procedure as shown in Fig. 2b. As a first step, pristine [Emim]Ac was dried in a vacuum oven at $75^{\circ} \mathrm{C}$ for $24 \mathrm{~h}$ and used for the initial experimental treatments. Freeze drying was used to remove water from the filtrate containing the recovered [Emim]Ac, and the remainder was further dried in a vacuum oven at $75{ }^{\circ} \mathrm{C}$ for $24 \mathrm{~h}$. The recovered [Emim] Ac was directly used for the next cycle of pretreatment without any purification.

\section{Enzymatic saccharification}

Untreated and pretreated [Emim]Ac wood meals $(20 \mathrm{mg}$ after oven drying) were suspended in $1.0 \mathrm{~mL}$ of $0.05 \mathrm{M}$ acetic acid buffer solution ( $\mathrm{pH} 4.5$ ) with 45 filter paper units (FPU) of GC220 enzyme for each gram of cellulose at $45^{\circ} \mathrm{C}$ for $24 \mathrm{~h}$. The enzyme was deactivated by heating at $100{ }^{\circ} \mathrm{C}$ for $5 \mathrm{~min}$, and the released glucose was analyzed with an ion chromatograph (ICS 3000, Thermo, USA).

\section{Analysis of carbohydrates}

Glucose liberation values were calculated from the glucose released from enzymatic saccharification relative to glucose contents in the residues. Each residue sample (20 mg after oven drying) was first hydrolyzed with $72 \%$ sulfuric acid at room temperature for $2.5 \mathrm{~h}$ and then hydrolyzed with $4 \%$ sulfuric acid at $121^{\circ} \mathrm{C}$ for $1 \mathrm{~h}$. After the hydrolysis, arabinose, galactose, glucose, xylose, and mannose were determined using an ion chromatograph [20]. Specifically, the monosaccharide contents were determined on a Dionex ICS 3000 ion chromatograph (Dionex, Sunnyvale, CA, USA) from a filtrate at 1000-fold dilution. The system consisted of an electrochemical detector (ED), a single pump model (SP1), and a CarboPac PA 1 column $(250 \mathrm{~mm} \times 4 \mathrm{~mm}$ i.d. $)$, CarboPac PA 1 guard column ( $250 \mathrm{~mm} \times 4 \mathrm{~mm}$ i.d.), and an autosampler (AS). 


\section{Elemental analysis}

The adsorption of [Emim]Ac was evaluated by the nitrogen content from elemental analysis (Perkin-Elmer 2400 CHN Elemental Analyzer from the Research Facility Center for Science and Technology, University of Tsukuba).

\section{Analysis of acid-insoluble lignin (Klason lignin)}

Acid-insoluble lignin (Klason lignin) was analyzed by hydrolysis, according to the method described elsewhere [21]. A sample was weighed ( $0.5 \mathrm{~g}$ after oven drying) and treated with the two-step hydrolyzation using sulfuric acid, as described above. The residue was collected on a glass filter (1GP16), and its weight was measured as acid-insoluble lignin.

\section{Measurement of dissolved lignin in the filtrate}

The filtrates were diluted to $500 \mathrm{~mL}$ and adjusted to $\mathrm{pH} 5.0$ using acetic acid. The lignin content in the filtrate was determined by UV absorbance at $300 \mathrm{~nm}$, based on the absorption coefficient of $17.2 \mathrm{~L} \mathrm{~g}^{-1} \cdot \mathrm{cm}^{-1}$ obtained from alkali lignin (Aldrich Chemical Company Inc., USA).

\section{X-ray diffraction analysis}

Untreated and treated wood meals were sieved to $40-80$ mesh size. Their crystallinity was measured by a full-automatic multi-purpose X-ray diffractometer (XRD, D8 Advance/TSM, BrukerTSM, Germany) at $20^{\circ} \mathrm{C}$ (voltage $40 \mathrm{kV}, 40 \mathrm{~mA}$ ) with $\mathrm{Cu}-\mathrm{K} \alpha$ source $\left(\lambda=1.54 \AA\right.$ ). The angular range was $10-30^{\circ}$ with a step size of $0.03^{\circ}$ and a step time of $0.05 \mathrm{~s}$. The XRD data was used to calculate the crystallinity index $\left(C_{\mathrm{r}} I\right)$ according to the following formula:

$C_{\mathrm{r}} I=\frac{I_{002}-I_{\mathrm{am}}}{I_{002}} \times 100$ where $I_{002}$ is the maximum intensity of the $I_{002}$ lattice diffraction between $2 \theta=21-23^{\circ}$, and $I_{\mathrm{am}}$ is the minimum diffraction intensity of the amorphous background between $2 \theta=17-19^{\circ}$.

\section{Results and discussion}

\section{Effect of [Emim]Ac pretreatment on softwood dissolution and cellulose regeneration}

The liberated glucose and chemical components of the rewashed residue, the regenerated cellulose, and the filtrate from separation procedure (as explained in Fig. 2a) are shown in Table 1 . Pretreatment at $80^{\circ} \mathrm{C}$ for a relatively long time $(72 \mathrm{~h})$ resulted in a low dissolution ratio of softwood (24.7\%). The very low solubility of wood flour in [Emim]Ac contrasts with the high solubility of free cellulose, because the presence of lignin lowers the solubility of lignocellulose [2]. The lignin weight of the rewashed residue after $72 \mathrm{~h}$ treatment was $25.5 \%$. This indicates that only $26.1 \%$ of lignin was dissolved. It was shown that [Emim]Ac pretreatment was not effective for removing lignin, and the same conclusion was reached by Mood et al. [16]. This result differs from that of Lee et al., who used [Emim]Ac to treat maple wood powder to achieve high lignin solubility [15].

Most researchers focus on complete dissolution of lignocellulosic materials in ILs to produce regenerated cellulose, followed by cellulose hydrolysis with acid or enzyme [2, 5]. In contrast, in our study, pretreatment at $80{ }^{\circ} \mathrm{C}$ for $72 \mathrm{~h}$ resulted in low regenerated cellulose (12.6\%), as most of the cellulose did not dissolve and remained in the rewashed residue. The yield of the rewashed residue was 75.3\% (Table 1). These results clarified that the [Emim]Ac pretreatment could not completely dissolve the softwood or effectively produce regenerated cellulose.

Table 1 Chemical compositions of softwood materials and products obtained in the separation procedure after 1-ethyl-3-methylimidazolium acetate $([\mathrm{Emim}] \mathrm{Ac})$ pretreatment at $80{ }^{\circ} \mathrm{C}$ for $72 \mathrm{~h}$

\begin{tabular}{lllllllrr}
\hline & Yields (\%) & Lignin $(\%)^{\mathrm{a}}$ & Glucan $(\%)$ & Mannan $(\%)$ & Xylan $(\%)$ & $\begin{array}{l}\text { Arabinan and } \\
\text { galactan }(\%)\end{array}$ & Other $(\%)$ & Nitrogen $(\%)^{\mathrm{b}}$ \\
\hline Untreated wood & 100 & 34.5 & 40.9 & 7.9 & 5.1 & 3.2 & $8.4^{\mathrm{c}}$ & 0.0 \\
Residue & 105 & 26.0 & 38.1 & 5.0 & 3.3 & 1.9 & 30.8 & 4.1 \\
Rewashed residue & 75.3 & 25.5 & 28.3 & 4.0 & 2.5 & 1.5 & 13.5 & 0.9 \\
Regenerated cellulose & 12.6 & 2.0 & 5.3 & 1.2 & 0.2 & 0.1 & 3.8 & 0.6 \\
Filtrate & 12.1 & - & 0.2 & 0.1 & 0.6 & 0.5 & 10.7 & - \\
\hline
\end{tabular}

${ }^{\mathrm{a}}$ Klason lignin

${ }^{\mathrm{b}}$ Elemental analysis

${ }^{\mathrm{c}}$ It includes ash content: $0.4 \%$ 


\section{Enzymatic saccharification of residue and regenerated cellulose}

The total of the liberated residue and regenerated cellulose were more than $100 \%$ before rewashing the residue with distilled water. Elemental analysis revealed that [Emim]Ac was adsorbed into the residue. The proportion of adsorbed [Emim]Ac was reduced from 25.1 to 3.9\% (based on residue weight) by rewashing using distilled water. The rewashing also increased the degree of glucose liberation of the residue from 51.1 to $90.1 \%$. The digestion of regenerated cellulose (which contained 5.3\% [Emim] Ac) was around 100\% (Table 2). These results indicated that the presence of $25 \%$ [Emim]Ac affected the performance of the cellulase, but the cellulase could work effectively when the [Emim]Ac was reduced to $<5 \%$. Wang et al. reported that an [Emim]Ac content of $<15 \%$ was compatible with the cellulase mixture, and a high activity was retained for hydrolyzing Avicel and yellow poplar [22]. Therefore, a small amount of [Emim]Ac does not prohibit the saccharification process. This conclusion could help with the large-scale applications of the pretreatment process, because a specific threshold of residual IL could make the operation more difficult.

The glucose liberation of the rewashed residue (which contained $33.8 \%$ lignin) was $90.1 \%$, a value that is higher than that of filter paper (64\%) (Table 2). The liberation of glucose from the regenerated cellulose was more than $100 \%$ (a value which was calculated based on the glucose content obtained from the hydrolysis method using 72 and $4 \%$ sulfuric acid), even when the substrate contained $15.8 \%$ lignin. Thus, it suggests that the pretreatment using [Emim] Ac can facilitate the enzymatic saccharification of cellulose, either with producing regenerated cellulose or using the simpler processes.

\section{Pretreatment without separating regenerated cellulose}

Wood meals $(0.5 \mathrm{~g})$ was pretreated with $10 \mathrm{~g}$ [Emim]Ac using the simpler procedure (i.e., without collecting regenerated cellulose) at 60,80 , and $100{ }^{\circ} \mathrm{C}$ for $2,4,6$, and $8 \mathrm{~h}$, according to the scheme described in Fig. $2 \mathrm{~b}$. The results showed a low dissolution of softwood, as $91.7-98.9 \%$ of the pretreated wood remained as residues (Tables 3, 4).

The color of the filtrate became darker with increasing time and temperature of the pretreatment, because of the dissolved wood components in the filtrate. Lignin contents in the filtrate determined with the UV-Vis spectrophotometer were $1.9-7.9 \%$ of the wood materials. From these results, the lignin contents in the residues at $80{ }^{\circ} \mathrm{C}$ after 2 , 4 , and $8 \mathrm{~h}$ were calculated to be $31.4,31.0$, and $29.6 \%$, respectively (Table 4). Using the same pretreatment time and temperature, lignin contents in the residue were analyzed using Klason lignin method (Table 3), resulting in $31.4 \%, 30.5 \%$, and
Table 2 Enzymatic saccharification of softwood products obtained in the separation procedure after 1-ethyl-3-methylimidazolium acetate $([$ Emim $] \mathrm{Ac})$ pretreatment at $80{ }^{\circ} \mathrm{C}$ for $72 \mathrm{~h}$

\begin{tabular}{llllll}
\hline & $\begin{array}{l}\text { Glucose in 20 mg } \\
\text { of initial sample }\end{array}$ & $\begin{array}{l}\text { Lignin } \\
\text { content }(\%)^{\mathrm{a}}\end{array}$ & $\begin{array}{l}\text { [Emim]Ac } \\
\text { content }(\%)^{\mathrm{b}}\end{array}$ & $\begin{array}{l}\text { Liberated } \\
\text { glucose }(\mathrm{mg})\end{array}$ & $\begin{array}{l}\text { Glucose } \\
\text { Liberation }(\%)^{\mathrm{c}}\end{array}$ \\
\hline Filter paper & 22.2 & - & - & 13.8 & 62.2 \\
Untreated wood & 9.1 & 34.5 & - & 0.6 & 6.1 \\
Residue & 8.1 & 26.0 & 25.1 & 4.1 & 51.1 \\
Rewashed residue & 8.3 & 33.8 & 3.9 & 7.5 & 90.1 \\
Regenerated cellulose & 9.3 & 15.8 & 5.3 & 10.4 & $>100$ \\
\hline
\end{tabular}

${ }^{a}$ Klason lignin

${ }^{\mathrm{b}}$ Calculated from nitrogen content of samples relative to nitrogen content in [Emim]Ac by elemental analysis

${ }^{\mathrm{c}}$ Calculated from liberated glucose levels generated by enzymatic saccharification relative to glucose content in the pretreated wood meals

Table 3 Adsorption of 1-ethyl-3-methylimidazolium acetate ([Emim]Ac) relative to the residue obtained in the proposed non-separation procedure

\begin{tabular}{|c|c|c|c|c|c|c|c|c|}
\hline Conditions & Residue weight (\%) & {$[$ Emim]Ac $(\%)$} & $\operatorname{Lignin}(\%)^{\mathrm{a}}$ & Glucan (\%) & Mannan (\%) & Xylan (\%) & $\begin{array}{l}\text { Arabinan and } \\
\text { galactan }(\%)\end{array}$ & Other $(\%)$ \\
\hline $80{ }^{\circ} \mathrm{C}, 2 \mathrm{~h}$ & $96.6 \pm 0.5$ & 4.6 & 31.4 & 32.4 & 6.3 & 4.0 & 2.2 & 15.7 \\
\hline $80^{\circ} \mathrm{C}, 4 \mathrm{~h}$ & $95.0 \pm 0.2$ & 4.4 & 30.5 & 35.5 & 6.7 & 4.4 & 2.3 & 11.2 \\
\hline $80^{\circ} \mathrm{C}, 8 \mathrm{~h}$ & $94.9 \pm 0.2$ & 3.0 & 30.9 & 28.3 & 5.5 & 3.6 & 1.9 & 21.7 \\
\hline
\end{tabular}

${ }^{\mathrm{a}}$ Klason lignin 
Table 4 Effects of 1-ethyl-3-methylimidazolium acetate ([Emim]Ac) pretreatment on the dissolution of softwood components

\begin{tabular}{|c|c|c|c|c|c|}
\hline \multirow{2}{*}{$\begin{array}{l}\text { Pretreat- } \\
\text { ment } \\
\text { conditions }\end{array}$} & \multirow{2}{*}{$\begin{array}{l}\text { Residue } \\
\text { weight } \\
(\%)\end{array}$} & \multirow[t]{2}{*}{$\begin{array}{l}{[\text { Emim] }} \\
\text { Ac }(\%)^{\mathrm{a}}\end{array}$} & \multicolumn{2}{|c|}{$\begin{array}{l}\text { Organic compounds in } \\
\text { filtrate }\end{array}$} & \multirow{2}{*}{$\begin{array}{l}\text { Lignin } \\
\text { content } \\
\text { in residue } \\
(\%)^{\mathrm{d}}\end{array}$} \\
\hline & & & Total $(\%)^{\mathrm{b}}$ & $\begin{array}{l}\text { Lignin } \\
(\%)^{c}\end{array}$ & \\
\hline
\end{tabular}

$60{ }^{\circ} \mathrm{C}$

\section{$2 \mathrm{~h}$}

$4 \mathrm{~h}$

$6 \mathrm{~h}$

$8 \mathrm{~h}$

$$
98.8
$$

$$
0.9
$$

2.1

$$
98.9
$$

$$
1.6
$$

$$
2.7
$$

1.9
2.3

\section{6}

98.1

$1.3 \quad 3.2$

2.3

3.0

$80{ }^{\circ} \mathrm{C}$

\begin{tabular}{cccccc}
$2 \mathrm{~h}$ & 96.6 & 1.3 & 4.7 & 3.1 & 31.4 \\
$4 \mathrm{~h}$ & 95.0 & 2.2 & 7.2 & 3.5 & 31.0 \\
$6 \mathrm{~h}$ & 95.0 & 1.6 & 6.6 & 4.9 & 29.6 \\
$8 \mathrm{~h}$ & 94.9 & 2.2 & 7.3 & 4.9 & 29.6 \\
$100^{\circ} \mathrm{C}$ & & & & & \\
$2 \mathrm{~h}$ & 96.6 & 1.8 & 5.2 & 4.1 & 30.4 \\
$4 \mathrm{~h}$ & 94.9 & 0.9 & 5.9 & 5.4 & 29.1 \\
$6 \mathrm{~h}$ & 94.5 & 2.2 & 7.7 & 5.7 & 28.8 \\
$8 \mathrm{~h}$ & 91.7 & 2.7 & 11.0 & 7.9 & 26.6 \\
\hline
\end{tabular}

${ }^{\mathrm{a} C a l c u l a t e d ~ f r o m ~ n i t r o g e n ~ c o n t e n t ~ o f ~ s a m p l e s ~ r e l a t i v e ~ t o ~ n i t r o g e n ~ c o n-~}$ tent in [Emim]Ac by elemental analysis

${ }^{\mathrm{b}} 100-($ residue $-[$ Emim $]$ Ac) $(\%)$

${ }^{\mathrm{c}} \mathrm{UV}$ absorbance at $300 \mathrm{~nm}$

${ }^{\mathrm{d}} 34.5$-lignin content in filtrate (\%)

$30.9 \%$. Lignin determination by Klason lignin gave results similar to that measured with an indirect method using UV-Vis spectrophotometer analysis. Both sets of data demonstrate that lignin contents in the residue remained high.

\section{Effects of non-separation pretreatment on glucose liberation and cellulose crystallinity}

Separation procedure aimed at producing regenerated cellulose involves relatively long steps. Pretreatment at $80{ }^{\circ} \mathrm{C}$ for $72 \mathrm{~h}$, total yield of rewashed residue and regenerated cellulose is $87.9 \%$ (Table 1). The glucose liberated from the rewashed residue reached $90.1 \%$ (Table 2). On the other hand, in a non-separation procedure, at the same temperature $\left(80^{\circ} \mathrm{C}\right)$ and for a relatively short pretreatment period (6-8 h), the glucose released was $40.2-42.6 \%$. Glucose liberation after pretreatment at $100{ }^{\circ} \mathrm{C}$ for $8 \mathrm{~h}$ was $85.9 \%$ (Table 5), almost the same as that obtained after a relatively long pretreatment period $\left(80^{\circ} \mathrm{C}, 72 \mathrm{~h}\right)$. Thus, it can be concluded that the non-separation procedure is also appropriate for glucose liberation.

Two XRD peaks at $15^{\circ}$ and $22.5^{\circ}$ were clearly observed in the untreated wood samples and microcrystalline cellulose, indicating the presence of crystalline cellulose I [23,
Table 5 Enzymatic saccharification of softwood products obtained in the non-separation procedure after 1-ethyl-3-methylimidazolium acetate $([\mathrm{Emim}] \mathrm{Ac})$ pretreatment at various conditions

\begin{tabular}{cllll}
\hline $\begin{array}{l}\text { Pretreat- } \\
\text { ment condi- } \\
\text { tions }\end{array}$ & $\begin{array}{l}\text { Glucose in } \\
20 \mathrm{mg} \text { of initial } \\
\text { sample }\end{array}$ & $\begin{array}{l}\text { Crystallin- } \\
\text { ity index } \\
(\%)\end{array}$ & $\begin{array}{l}\text { Liberated } \\
\text { glucose } \\
(\mathrm{mg})\end{array}$ & $\begin{array}{l}\text { Glucose } \\
\text { liberation } \\
(\%)^{\mathrm{a}}\end{array}$ \\
\hline $60^{\circ} \mathrm{C}$ & & & & \\
$2 \mathrm{~h}$ & 9.5 & 38.9 & 1.7 & 18.2 \\
$4 \mathrm{~h}$ & 9.6 & 39.4 & 1.6 & 16.5 \\
$6 \mathrm{~h}$ & 9.6 & 36.4 & 1.9 & 19.6 \\
$8 \mathrm{~h}$ & 9.6 & 35.7 & 1.7 & 17.5 \\
$80{ }^{\circ} \mathrm{C}$ & & & & \\
$2 \mathrm{~h}$ & 9.9 & 35.1 & 2.8 & 28.7 \\
$4 \mathrm{~h}$ & 9.7 & 33.3 & 3.5 & 35.9 \\
$6 \mathrm{~h}$ & 9.4 & 30.6 & 3.8 & 40.3 \\
$8 \mathrm{~h}$ & 8.8 & 30.6 & 3.8 & 42.6 \\
$100{ }^{\circ} \mathrm{C}$ & & & & \\
$2 \mathrm{~h}$ & 9.9 & 29.8 & 4.5 & 45.9 \\
$4 \mathrm{~h}$ & 8.8 & 28.7 & 5.3 & 60.6 \\
$6 \mathrm{~h}$ & 8.3 & 28.1 & 5.7 & 68.6 \\
$8 \mathrm{~h}$ & 8.5 & 28.1 & 7.3 & 85.9 \\
\hline
\end{tabular}

${ }^{\mathrm{a} C a l c u l a t e d}$ from liberated glucose levels generated by enzymatic saccharification relative to glucose content in the pretreated wood meals

24]. The peaks of residues became flattened upon increasing the treatment temperature (Fig. 3) and time (data not shown). These weak diffraction patterns are attributed mainly to the conversion of crystalline cellulose into amorphous cellulose $[23,24]$. The $C_{\mathrm{r}} I$ values of microcrystalline cellulose, untreated softwood, and residues were 82.5, 50.9, and $37.1-28.4 \%$, respectively.

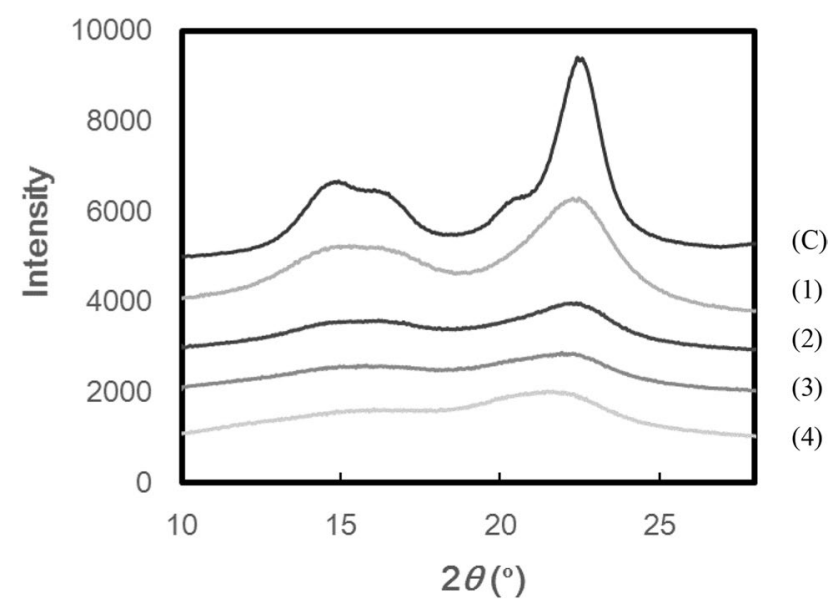

Fig. 3 Effects of [Emim]Ac pretreatment on cellulose crystallinity (XRD patterns). $C$ microcrystalline cellulose, 1 untreated wood, 2 pretreated at $60{ }^{\circ} \mathrm{C}$ for $6 \mathrm{~h}, 3$ pretreated at $80^{\circ} \mathrm{C}$ for $6 \mathrm{~h}$, and 4 pretreated at $100{ }^{\circ} \mathrm{C}$ for $6 \mathrm{~h}$ 
The lowest glucose liberation in the residues was found to be $16.5 \%$ after pretreatment at $60{ }^{\circ} \mathrm{C}$ for $4 \mathrm{~h}$ (Table 5). This percentage is still about 3 times that of untreated wood $(5.1 \%)$. Glucose liberation after pretreatment at $100{ }^{\circ} \mathrm{C}$ for 6 and $8 \mathrm{~h}$ were 68.6 and $85.1 \%$, respectively. These results are higher than that from filter paper (61.4\%). Under moderate pretreatment conditions $\left(80^{\circ} \mathrm{C}\right.$ for 6 and $\left.8 \mathrm{~h}\right)$, the respective liberation ratios were 40.3 and $42.6 \%$. The amount of lignin left in these residues were in the range of 26.6-32.6\% (Table 4). Hence, the glucose liberation was successfully increased by the [Emim]Ac pretreatment, even though the residues contained high amounts of lignin.

A good correlation between the decreasing $C_{\mathrm{r}} I$ of cellulose and the increasing enzymatic saccharification efficiency was observed at $80{ }^{\circ} \mathrm{C}\left(R^{2}=0.9579\right)$ and $100{ }^{\circ} \mathrm{C}$ $\left(R^{2}=0.7913\right)$. However, the correlation became quite weak at $60{ }^{\circ} \mathrm{C}\left(R^{2}=0.2118\right)$ : pretreatment for $2-8 \mathrm{~h}$ reduced $C_{\mathrm{r}} I$ to $23-30 \%$, which did not correlate well with the glucose liberation values. The significant reduction in $C_{\mathrm{r}} I$ confirms that the pretreated samples were highly amorphous, and thus the cellulose surface became much more accessible during enzymatic saccharification [2, 15, 24]. Ichiura et al. [25] observed that with the partial dissolution of cellulose fibers at $80^{\circ} \mathrm{C}$ using a $[\mathrm{Bmim}] \mathrm{Cl}$ treatment, the resulting $C_{\mathrm{r}} I$ values decreased. Scanning electron microscope (SEM) images further showed that the regenerated cellulose tended to aggregate and form a cellulose film on the surface. Their results may provide an explanation for our findings that suggest that cellulose amorphization, with decreasing $C_{\mathrm{r}} I$, in the softwood residue was achieved by the pretreatment process with lower solubility.

\section{Recovery and reuse of [Emim]Ac}

The high-cost of imidazolium cations, which are chemically synthesized from petroleum sources, is one major obstacle to the large-scale industrial application of imidazolium-based ILs for biomass pretreatment [8]. Therefore, the recovery and reuse of ILs are necessary. The presence of water in the ILs is usually detrimental to the dissolution of biomass $[8,15,19,25]$. For example, the function of the recovered $[\mathrm{Bmim}] \mathrm{Cl}$ was lower than the function of pure $[\mathrm{Bmim}] \mathrm{Cl}$ if it contained any water. Otherwise, the functionality was similar with pure [Bmim] $\mathrm{Cl}$ [25]. In this work, water in the filtrate was removed by a freeze drying process, and then further dried in a vacuum oven to attain less than $1.0 \%$ of moisture content $[15,25]$. Without further purification, the recovered [Emim]Ac was recycled and reused to pretreat wood meals, resulting in the accumulation of dissolved materials.

Since the influence of moisture on the recycling of ionic liquid has already been clarified in many papers, the influence of lignin was examined herein. It is desirable that the
Table 6 Reuse of 1-ethyl-3-methylimidazolium acetate ([Emim]Ac) for softwood pretreatment at $80^{\circ} \mathrm{C}$ for $6 \mathrm{~h}$

\begin{tabular}{lllll}
\hline $\begin{array}{l}\text { Times of reus- } \\
\text { ing [Emim]Ac }\end{array}$ & $\begin{array}{l}\text { Residue } \\
\text { weight } \\
(\%)\end{array}$ & $\begin{array}{l}\text { Lignin content } \\
\text { in filtrate }(\%)^{\mathrm{a}, \mathrm{b}}\end{array}$ & $C_{\mathrm{r}} I(\%)$ & $\begin{array}{l}\text { Glucose } \\
\text { liberation } \\
(\%)^{\mathrm{c}}\end{array}$ \\
\hline None & 95.3 & 5.5 & 32.5 & 48.6 \\
First & 97.8 & $10.8(5.3)$ & 32.5 & 52.6 \\
Second & 97.1 & $17.3(6.5)$ & 30.7 & 49.0 \\
Third & 96.6 & $22.4(5.1)$ & 34.0 & 46.2 \\
\hline
\end{tabular}

${ }^{\mathrm{a}} \mathrm{UV}$ absorbance at $300 \mathrm{~nm}$

${ }^{\mathrm{b}}$ Values in parentheses indicate incremental lignin dissolved for each reuse

${ }^{\mathrm{c} C a l c u l a t e d ~ f r o m ~ l i b e r a t e d ~ g l u c o s e ~ l e v e l s ~ g e n e r a t e d ~ b y ~ e n z y m a t i c ~ s a c-~}$ charification relative to glucose content in the pretreated wood meals

lignin content in the organic compounds of filtrate is high. Considering the presence of lignin in the organic compounds of the filtrate, the residue yield ( $95 \%)$, the medium glucose liberation, crystallinity index $(\sim 30 \%)$, and low temperature, the recycling experiment was performed at $80^{\circ} \mathrm{C}$ for $6 \mathrm{~h}$.

The percentage of lignin in the recovered [Emim] Ac increased with the recycling, reaching $22.4 \%$ after the $3 \mathrm{rd}$ reuse (which corresponds to an average increase of $5.6 \%$ in dissolved lignin per cycle, Table 6). Even though the lignin content in the pretreated wood remained high, and the amount of lignin dissolved in the filtrate increased, the liberation of glucose by enzymatic saccharification was unaffected. Findings showed that the glucose liberation was equally successful between pristine [Emim]Ac and recovered [Emim]Ac up until the 3rd cycle. This is consistent with the results of Weerachanchai and Lee, who observed the deterioration of reused IL in the 5th-7th batches using thermogravimetric analysis (TGA) and ${ }^{1} \mathrm{H}$-nuclear magnetic resonance (NMR) spectroscopy [19].

\section{Conclusions}

It is essential to develop suitable and efficient methods for [Emim]Ac pretreatment of softwood. This study clarified that $[$ Emim]Ac does not have a strong effect on softwood dissolution. Hence, it is not efficient, if producing regenerated cellulose and removing lignin are the focuses. Despite the large fraction of residues containing high amounts of lignin, the glucose liberation of pretreated softwood by enzymatic saccharification was significantly increased compared to untreated wood. It was demonstrated that [Emim] Ac substantially reduced the crystallinity of cellulose and amorphized it, thereby increasing the glucose liberation by saccharification. [Emim]Ac was also successfully recycled for at least 3 cycles without performance loss, even though the dissolved lignin accumulated. 
Acknowledgements The study was partly supported by a Grant-in-Aid for Challenging Exploratory Research (JP26660138) from the Japan Society for the Promotion of Science (JSPS) KAKENHI.

\section{Compliance with ethical standards}

Conflict of interest The authors declare that they have no conflict of interest.

\section{References}

1. Ministry of Agriculture, Forestry and Fisheries, Japan (2015) Annual report on forest and forestry in Japan FY 2015 (summary), Japan. pp 9-19. http://www.rinya.maff.go.jp/j/kikaku/ hakusyo/27hakusyo/attach/pdf/index-1.pdf. Accessed 24 July 2017

2. Xiao W, Yin W, Xia S, Ma P (2012) The study of factors affecting the enzymatic hydrolysis of cellulose after ionic liquid pretreatment. Carbohyd Polym 87:2019-2023

3. Li B, Asikkala J, Filpponen I, Argyropoulos DS (2010) Factors affecting wood dissolution and regeneration of ionic liquids. Ind Eng Chem Res 49:2477-2484

4. Fort DA, Remsing RC, Swatloski RP, Moyna P, Moyna G, Rogers RD (2007) Can ionic liquids dissolve wood? Processing and analysis of lignocellulosic materials with 1- $n$-butyl-3-methylimidazolium chloride. Green Chem 9:63-69

5. Kilpeläinen I, Xie H, King A, Granstrom M, Heikkinen S, Argyropoulos DS (2007) Dissolution of wood in ionic liquids. J Agric Food Chem 55:9142-9148

6. Sun N, Rahman M, Qin Y, Maxim ML, Rodríguez H, Rogers RD (2009) Complete dissolution and partial delignification of wood in the ionic liquid 1-ethyl-3-methylimidazolium acetate. Green Chem 11:646-655

7. Miyafuji H, Suzuki N (2012) Morphological changes in sugi (Cryptomeria japonica) wood after treatment with the ionic liquid, 1-ethyl-3-methylimidazolium chloride. J Wood Sci 58:222-230

8. Hou Q, Ju M, Li W, Liu L, Chen Y, Yang Q (2017) Pretreatment of lignocellulosic biomass with ionic liquids and ionic liquid-based solvent systems. Molecules 22:490

9. Swatloski RD, Spear SK, Holbrey JD, Rogers RD (2002) Dissolution of cellulose with ionic liquids. J Am Chem Soc 124:4974-4975

10. Mäki-Arvela P, Anugwom I, Virtanen P, Sjöholm R, Mikkola JP (2010) Dissolution of lignocellulosic materials and its constituents using ionic liquids-A review. Indus Crops Prod 32:175-201

11. Kanbayashi T, Miyafuji H (2014) Comparative study of morphological changes in hardwoods treated with the ionic liquid, 1-ethyl-3-methylimidazolium chloride. J Wood Sci 60:152-159
12. Miyafuji H, Miyata K, Saka S, Ueda F, Mori M (2009) Reaction behaviour of wood in an ionic liquid, 1-ethyl-3-methylimidazolium chloride. J Wood Sci 55:215-219

13. Kishino M, Taniguchi R, Nakagawa-izumi A, Ohi H (2009) Chemical characteristics of wood materials treated with an ionic liquid, 1-n-butyl-3-methylimidazolium chloride. Mokuzai Gakkaishi (in Japanese) 55:243-248

14. Mood SH, Golfeshan AH, Tabatabaei M, Abbasalizadeh S, Ardjmand M (2013) Comparison of different ionic liquids pretreatment for barley straw enzymatic saccharification. Biotech 3:399-406

15. Lee SH, Doherty TV, Linhardt RJ, Dordick JS (2009) Ionic liquid-mediated selective extraction of lignin from wood leading to enhanced enzymatic cellulose hydrolysis. Biotechnol Bioeng 102:1368-1376

16. Rollin JA, Zhu Z, Sathitsuksanoh N, Zhang YHP (2011) Increasing cellulose accessibility is more important than removing lignin: a comparison of cellulose solvent-based lignocellulose fractionation and soaking in aqueous ammonia. Biotechnol Bioeng 108:22-30

17. Sathitsuksanoh N, George A, Zhang YHP (2012) New lignocellulose pretreatments using cellulose solvents: a review. J Chem Technol Biotechnol 88:169-180

18. Hall M, Bansal P, Lee JH, Realff MJ, Bommarius AS (2010) Cellulose crystallinity - a key predictor of the enzymatic hydrolysis rate. FEBS J 277:1571-1582

19. Weerachanchai P, Lee JM (2014) Recyclability of an ionic liquid for biomass pretreatment. Bioresour Technol 169:336-343

20. Tanifuji K, Takahashi S, Kajiyama M, Ohi H (2011) Advantage of acid sulfite cooking as process of bioethanol production. Jpn TAPPI J 65:494-505

21. Lin SY, Dence CW (1992) Methods in lignin chemistry. Springer, Tokyo (Chap. 2.2)

22. Wang Y, Radosevich M, Hayes D, Labbé N (2011) Compatible ionic liquid-cellulases system for hydrolysis of lignocellulosic biomass. Biotechnol Bioeng 108:1042-1048

23. Cheng G, Varanasi P, Li C, Liu H, Melnichenko YB, Simmons BA, Kent MS, Singh S (2011) Transition of cellulose crystalline structure and surface morphology of biomass as a function of ionic liquid pretreatment and its relation to enzymatic hydrolysis. Biomacromol 12:933-941

24. Zhang J, Wang Y, Zhang L, Zhang R, Liu G, Cheng G (2014) Understanding changes in cellulose crystalline structure of lignocellulosic biomass during ionic liquid pretreatment by XRD. Bioresour Technol 151:402-405

25. Ichiura H, Hirose Y, Masumoto M, Ohtani Y (2017) Ionic liquid treatment for increasing the wet strength of cellulose paper. Cellulose 24:3469-3477 